\title{
A STUDY ON PLASMA BIOCHEMICAL PHENOMENA IN HYPOXIC-ISCHAEMIC ENCEPHALOPATHY CASES IN TERTIARY CARE HOSPITAL
}

\author{
Leena Das ${ }^{1}$, Mangal Charan Murmu², Bibhudutta Nayak ${ }^{3}$ \\ ${ }^{1}$ Associate Professor, Department of Paediatrics, SCB Medical College, Cuttack, Odisha. \\ ${ }^{2}$ Associate Professor, Department of Paediatrics, SCB Medical College, Cuttack, Odisha. \\ ${ }^{3}$ Resident, Department of Paediatrics, SCB Medical College, Cuttack, Odisha.
}

\section{ABSTRACT}

\section{BACKGROUND}

Perinatal asphyxia can lead to hypoxic ischaemic encephalopathy (HIE). The mortality due to hypoxic ischaemic encephalopathy is as high as $28.8 \%$ and morbidity is $30 \%$ of surviving newborn due to hypoxic ischaemic encephalopathy.

Aims and Objectives- To study the plasma biochemical phenomena in neonates with hypoxic ischaemic encephalopathy in relation with severity of HIE.

\section{MATERIALS AND METHODS}

It is a hospital-based prospective study done in tertiary care hospital in SCB Medical College Hospital and SVP PG Institute, Cuttack from November 2015 to October 2017.

\section{RESULTS}

The babies with perinatal asphyxia develop hyponatraemia, hypocalcaemia, hyperkalaemia, high serum urea and creatinine, high serum ALT, AST, ALP, decrease in serum albumin and increase in Prothrombin time in proportion to the severity of asphyxia.

\section{CONCLUSION}

A significant number of babies with birth asphyxia and deranged biochemical parameters either died or discharged with severe neurological sequelae. It can be concluded that deranged biochemical parameters are early indicators of poor outcome. Studies should be held on the effects of early correction of these metabolic derangements with their outcomes, so that it may invent a new horizon of treatment for birth asphyxia babies.

\section{KEYWORDS}

Hypoxic-Ischaemic Encephalopathy, Apgar Score, Biochemical Phenomena.

HOW TO CITE THIS ARTICLE: Das L, Murmu MC, Nayak B. A study on plasma biochemical phenomena in hypoxic-ischaemic encephalopathy cases in tertiary care hospital. J. Evolution Med. Dent. Sci. 2018;7(14):1719-1726, DOI: $10.14260 /$ jemds/2018/389

\section{BACKGROUND}

Perinatal asphyxia is one of the most common primary causes of mortality (28.8\%) and morbidity among neonates in India and is the commonest cause of stillbirths (45.1\%).[1] Birth asphyxia is the most common and important cause of preventable cerebral injury occurring in the neonatal period. [2] Full recovery may not occur and many children are left with lifelong neurological impairment and in some cases incapacitating disability. [3] This creates a great burden for the family as well as for the society. According to World Health Organisation estimates in the developing countries 3\% of all infants (3.6 millions) suffer from moderate-to-severe birth asphyxia, of which $23 \%(840,000)$ die and approximately the same number develop serious sequelae.[4] Prevention is more important than treatment. Sodium, potassium and calcium are the major electrolytes in human body and any deviation from their normal levels in blood might cause convulsions,

'Financial or Other Competing Interest': None.

Submission 09-02-2018, Peer Review 17-03-2018,

Acceptance 22-03-2018, Published 02-04-2018.

Corresponding Author:

Mangal Charan Murmu

Qr. No. A/4, Sishubharan,

Chandini Chowk,

Cuttack-753002,

Odisha.

E-mail: mangal74murnu@yahoo.co.in

DOI: $10.14260 /$ jemds $/ 2018 / 389$

\section{(c) (i) $(9)$}

shock and other types of metabolic abnormalities. Calcium is an important second messenger in our body and also helps carrying out muscle function and acts as cofactor for several enzymatic activities. Body should maintain optimum level of these electrolytes in blood.[5] Perinatal asphyxia causes diminished oxidative phosphorylation and ATP production. This energy failure impairs ion pump function causing accumulation of intracellular sodium, chloride, water and calcium; extracellular potassium leading to electrolyte imbalance which affects the outcome of asphyxiated babies.[6]

The kidney is the most common organ to be affected in perinatal asphyxia.[6] The proximal tubule of the kidney is especially affected by decreased perfusion, leading to acute tubular necrosis with oliguria. Hence, blood urea nitrogen and serum creatinine may be elevated.

Liver cell injury commonly occurs after perinatal asphyxia and is similar to shock liver syndrome. It is represented as an early, abrupt and transient (within $24-72$ hours after) insult increase in aminotransferases [Aspartate transferase (AST) and alanine transferase (ALT)], alkaline phosphatase (ALP) and lactate dehydrogenase (LDH) plasma activity. Later on the peak aminotransferase level returns to near normal within 10 days.[7] The prognosis of hypoxic hepatitis itself is safe, and it rarely progresses into complete hepatic failure. With improved survival of sick asphyxiated neonates because of improvements in medical care, the clinical entity of liver involvement is being increasingly recognised, and so this work was planned to recognise the 
prevalence of liver involvement in birth asphyxia and to study the severity and type of hepatic dysfunction in relation to Apgar score and HIE grading of asphyxiated newborns.

Good supportive care is essential in the first 72 hours after asphyxia to prevent ongoing brain injury in the penumbra region. Strict monitoring and prompt correction is needed for common problems including temperature maintenance, blood sugar, blood pressure, serum electrolytes, renal parameters and oxygenation.

Studies to find out changes in serum sodium, potassium and calcium, liver enzyme levels in different degrees of asphyxia are still lacking.[5] Considering the above consequences of birth asphyxia, this study has been designed to observe the serum biochemical values in asphyxiated newborns and to correlate with different degree of asphyxia.

\section{Aims and Objectives}

To find out the levels of serum electrolytes $(\mathrm{Na}+, \mathrm{K}+, \mathrm{Ca} 2+)$ serum urea, serum creatinine, serum albumin, serum SGOT, serum SGPT, serum ALP, Prothrombin time in asphyxiated babies.

\section{MATERIALS AND METHODS}

After obtaining Ethical Committee clearance from the Institution, the present study was carried out in the Department of Paediatrics, SCB Medical College and Hospital, Cuttack and S.V.P.P.G.I.P, Cuttack from November 2015 to October 2017.

This was a prospective observational study. The study cohort consisted of the hospitalised term neonates of birth weight $\geq 2.5 \mathrm{~kg}$ to the indoors/ S.N.C.U of S.C.B M.C.H and S.V.P.P.G.I.P, Cuttack with diagnosis of birth asphyxia as per the following defined criteria. $\left.{ }^{7,8,9},\right]$

\section{Inclusion Criteria}

Apgar score $<7$ at 5 minutes of birth, 2. Delayed onset of respiration for $\geq 5$ minutes, 3 . Need for positive pressure ventilation at birth, 4. Metabolic acidosis (Cord Arterial Blood or Blood Gas Analysis within First Hour after Birth) indicated base deficit $\geq 16 \mathrm{mmol} / \mathrm{L}$. 5. Evidence of encephalopathy including altered state of consciousness and/ or seizures (Subtle/ tonic/ tonic-clonic types).

\section{Exclusion Criteria}

Preterm babies ( $<37$ Weeks of Gestational Age), 2. Babies with severe congenital malformations, 3. Suspected inborn errors of metabolism, 4. Congenital infections, 5. Babies receiving diuretics prior to evaluation, 6. IUGR babies, 7.Septic shock, 8. Low birth weight babies, 9. Babies to mothers suffering from renal diseases and on nephrotoxic drug.

Neonates presenting with perinatal asphyxia were studied according to pre-structured proforma where detail history regarding type and place of delivery, type of resuscitation required, any complication before/ during delivery, onset and duration of seizure and findings of clinical examination with special reference to central nervous system were noted and analysed according to the Sarnat and Sarnat staging system.[8]
In the present study, 150 cases were taken randomly as per the defined inclusion criteria.

\section{Investigations}

Blood samples were collected at the time of maximum Sarnat and Sarnat stage,[8] and sent for investigations. Following investigations were done in Department of Pathology and Biochemistry.

a. Complete blood count, b. CRP (Q), c. Serum electrolytes d. Serum urea, creatinine, e. ALT, f. AST, g. ALP, h. LDH, i.TSB, j. Serum Albumin and k. PT

Serum $\mathrm{Na}, \mathrm{K}$, Ca were estimated using electro-analyzer on the basis of ion-selective electrodes. Serum urea was estimated by using GLDH/ Kinetic method. Serum creatinine was estimated using Modified Kinetic Jaffe's method.

Serum ALT, AST, ALP and LHD were estimated by modified IFCC method.

\section{Management and Follow-Up}

Babies were followed up until discharge or death. Day-to-day check-up was done with particular stress on respiratory, cardiovascular, renal and neurological system examination. Asphyxiated babies were managed as per the standard protocol and with improvement of clinical status of newborns, orogastric/ nasogastric and subsequently oral feeding was selectively started after clinical evaluation.

Newborns were examined at the time of discharge to see for any focal neurological deficit, abnormal movements, feeding difficulty or persistent convulsions requiring continuation of anticonvulsant.

\section{Statistical Analysis}

Statistical analysis was done by statistical software SPSS for windows version 21 . $P$ values were calculated using chisquare test and ANOVA (Analysis Of Variance) with post-hoc test. $\mathrm{P}<0.05$ was considered as significant and $\mathrm{p}<0.01$ as highly significant.

The value obtained were plotted in predesigned proforma, analysed in the table.

\section{RESULTS}

\begin{tabular}{|c|c|c|c|c|c|}
\hline \multirow[b]{2}{*}{$\begin{array}{l}\text { Degree of } \\
\text { Asphyxia }\end{array}$} & \multicolumn{4}{|c|}{ Number of Cases } & \multirow[b]{2}{*}{ (\%) } \\
\hline & $\begin{array}{c}\text { Male } \\
\text { No. (\%) }\end{array}$ & \begin{tabular}{|l|} 
Female \\
No. (\%)
\end{tabular} & $\begin{array}{c}\text { M:F } \\
\text { Ratio }\end{array}$ & Total & \\
\hline HIE- 1 (Mild) & $\begin{array}{c}13 \\
(56.5)\end{array}$ & $\begin{array}{c}10 \\
(43.5)\end{array}$ & $1.3: 1$ & 23 & 15.33 \\
\hline HIE- 2 (Moderate) & $\begin{array}{c}73 \\
(84.9)\end{array}$ & $\begin{array}{c}13 \\
(15.1)\end{array}$ & $5.6: 1$ & 86 & 57.33 \\
\hline HIE- 3 (Severe) & $\begin{array}{c}30 \\
(73.2)\end{array}$ & $11(26.8)$ & $2.7: 1$ & 41 & 27.34 \\
\hline Total & $\begin{array}{c}116 \\
(77.3)\end{array}$ & $\begin{array}{c}34 \\
(22.7)\end{array}$ & $3.4: 1$ & 150 & 100 \\
\hline
\end{tabular}

Out of 150 cases of birth asphyxia, moderate asphyxia 86 cases (57.33\%) constitute the majority of cases and Male: Female ratio was $3.4: 1$. 


\begin{tabular}{|c|c|c|c|c|c|c|c|}
\hline Maturity & $\begin{array}{c}\text { HIE-1 } \\
\text { No. (\%) }\end{array}$ & $\begin{array}{c}\text { HIE-2 } \\
\text { No. }(\%)\end{array}$ & $\begin{array}{c}\text { HIE-3 } \\
\text { No. (\%) }\end{array}$ & $\begin{array}{c}\text { Total } \\
\text { No. }(\%)\end{array}$ & $\begin{array}{c}\text { P value* HIE-1 } \\
\text { vs HIE-2 }\end{array}$ & $\begin{array}{c}\text { P value* HIE-1 } \\
\text { vs HIE-3 }\end{array}$ & $\begin{array}{c}\text { P value* HIE-2 } \\
\text { vs HIE-3 }\end{array}$ \\
\hline Term & $20(87)$ & $47(54.7)$ & $19(46.3)$ & $86(57.3)$ & \multirow[b]{2}{*}{0.009} & \multirow[b]{2}{*}{0.003} & \multirow[b]{2}{*}{0.38} \\
\hline Post-term & 3 (13) & $\begin{array}{c}39 \\
(45.3)\end{array}$ & $\begin{array}{c}22 \\
(53.7)\end{array}$ & $\begin{array}{c}64 \\
(42.7)\end{array}$ & & & \\
\hline
\end{tabular}

${ }^{*}$ p value: Chi-square test applied with post-term as risk factor.

The incidence of severity of birth asphyxia increases with post maturity, as p value was $<0.01$.

\begin{tabular}{|c|c|c|c|c|c|c|c|}
\hline \multirow{2}{*}{ Mode of Delivery } & \multirow{2}{*}{$\begin{array}{c}\text { No. of Birth } \\
\text { Asphyxia } \\
\text { No. (\%) }\end{array}$} & \multicolumn{3}{|c|}{$\begin{array}{c}\text { Degree of Birth } \\
\text { Asphyxia No. (\%) }\end{array}$} & \multirow{2}{*}{$\begin{array}{l}\text { P value* HIE- } \\
1 \text { vs HIE-2 }\end{array}$} & \multirow{2}{*}{$\begin{array}{c}\text { P value* HIE } \\
1 \text { vs HIE-3 }\end{array}$} & \multirow{2}{*}{$\begin{array}{c}\text { P value* HIE } \\
2 \text { vs HIE-3 }\end{array}$} \\
\hline & & HIE-1 & HIE-2 & HIE-3 & & & \\
\hline $\begin{array}{l}\text { Normal delivery with } \\
\text { vertex presentation }\end{array}$ & $\begin{array}{c}72 \\
(48.0)\end{array}$ & $\begin{array}{c}11 \\
(47.8)\end{array}$ & $\begin{array}{c}46 \\
(53.5)\end{array}$ & $\begin{array}{c}15 \\
(36.6)\end{array}$ & 0.629 & 0.379 & 0.074 \\
\hline $\begin{array}{l}\text { Normal delivery with } \\
\text { abnormal } \\
\text { presentation(Breech) }\end{array}$ & $\begin{array}{c}31 \\
(20.7)\end{array}$ & $\begin{array}{c}3 \\
(13.1)\end{array}$ & $\begin{array}{c}23 \\
(26.7)\end{array}$ & $\begin{array}{c}5 \\
(12.2)\end{array}$ & 0.273 & 0.921 & 0.064 \\
\hline LSCS & $\begin{array}{c}13 \\
(8.7) \\
\end{array}$ & $\begin{array}{c}8 \\
(34.8) \\
\end{array}$ & $\begin{array}{c}3 \\
(3.5) \\
\end{array}$ & $\begin{array}{c}2 \\
(4.9) \\
\end{array}$ & 0.0001 & 0.005 & 0.706 \\
\hline $\begin{array}{c}\text { Forceps/ } \\
\text { Ventouse delivery }\end{array}$ & $\begin{array}{c}34 \\
(22.6)\end{array}$ & $\begin{array}{c}1 \\
(4.3)\end{array}$ & $\begin{array}{c}14 \\
(16.3)\end{array}$ & $\begin{array}{c}19 \\
(46.3)\end{array}$ & 0.256 & 0.001 & 0.0007 \\
\hline & Table & Deli & $\operatorname{th} D$ & Birt & yxia & & \\
\hline
\end{tabular}

*p value: Chi-square test applied

Severe degree of birth asphyxia was mostly seen in forceps/ ventouse delivery (46.3\%) and it was statistically significant as 'p' value was $<0.01$. LSCS was mostly associated with mild degree of asphyxia and it was statistically significant $(\mathrm{p}<0.01)$.

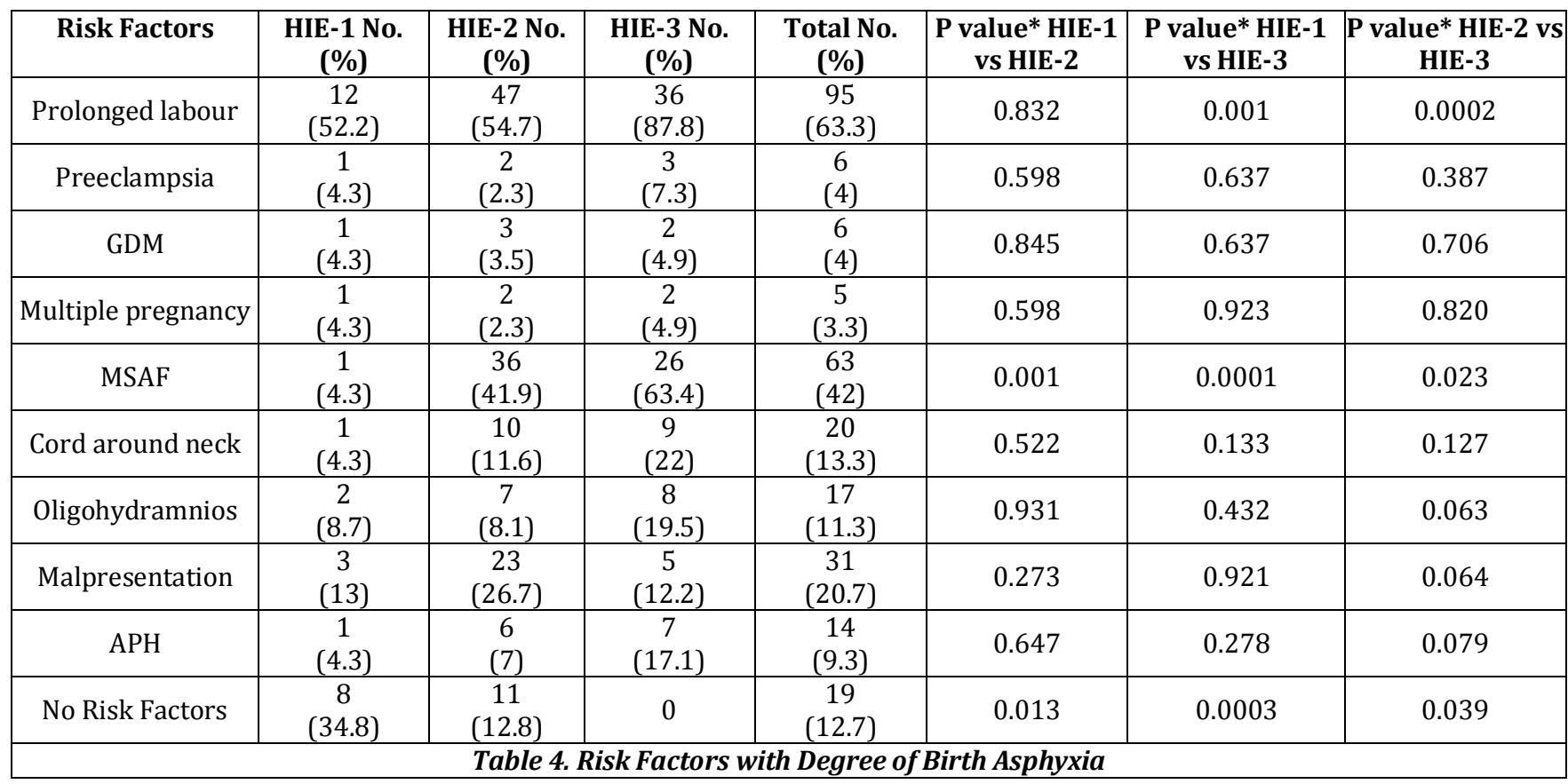

${ }^{*}$ p value: Chi-square test applied.

Prolonged labour (87.8\%) and meconium stained liquor (63.4\%) were more commonly seen in severe degree of birth asphyxia and they were statistically significant, as their ' $p$ ' values were $<0.01$. Severity of birth asphyxia increases when associated with different risk factors and it was statistically significant $(\mathrm{p}<0.05)$.

\begin{tabular}{|c|c|c|c|c|c|c|c|}
\hline Place of Delivery & $\begin{array}{c}\text { HIE-1 } \\
\text { No. (\%) }\end{array}$ & $\begin{array}{c}\text { HIE-2 } \\
\text { No. }(\%)\end{array}$ & $\begin{array}{c}\text { HIE-3 } \\
\text { No. }(\%) \\
\end{array}$ & $\begin{array}{c}\text { Total } \\
\text { No. }(\%) \\
\end{array}$ & \begin{tabular}{|c|}
$\begin{array}{c}\text { P value* HIE-1 } \\
\text { vs HIE-2 }\end{array}$ \\
\end{tabular} & \begin{tabular}{|c|}
$\begin{array}{c}\text { P value* HIE-1 } \\
\text { vs HIE-3 }\end{array}$ \\
\end{tabular} & \begin{tabular}{|c} 
P value* HIE-2 \\
vs HIE-3 \\
\end{tabular} \\
\hline Hospital & $\begin{array}{c}21 \\
(91.3)\end{array}$ & $\begin{array}{c}66 \\
(76.7)\end{array}$ & $\begin{array}{c}21 \\
(51.2)\end{array}$ & $\begin{array}{l}108 \\
(72)\end{array}$ & \multirow{3}{*}{0.210} & \multirow{3}{*}{0.003} & \multirow{3}{*}{0.0038} \\
\hline Outside hospital & $\begin{array}{c}2 \\
(8.7)\end{array}$ & $\begin{array}{c}20 \\
(23.3)\end{array}$ & $\begin{array}{c}20 \\
(48.8)\end{array}$ & $\begin{array}{c}42 \\
(28)\end{array}$ & & & \\
\hline Total & 23 & 86 & 41 & 150 & & & \\
\hline
\end{tabular}

${ }^{*}$ p value: Chi-square test applied with delivery outside the hospital as a risk factor.

Incidence of severity of birth asphyxia increased with delivery outside the hospital as compared to the hospital delivery and it was statistically significant as 'p' value was $<0.01$. 


\begin{tabular}{|c|c|c|c|c|c|c|}
\hline Biochemical & HIE-1 & HIE-2 & HIE-3 & P value* HIE & P value* HIE- & value* HIE- \\
\hline Parameters & $(X \pm S D)$ & $(X \pm S D)$ & $(X \pm S D)$ & 1 vs HIE-2 & 1 vs HIE-3 & 2 vs HIE-3 \\
\hline $\begin{array}{c}\text { Serum Na+ } \\
(\mathrm{mmol} / \mathrm{L})\end{array}$ & $137.5 \pm 3.8$ & $132.7 \pm 6.8$ & $124.4 \pm 4.4$ & $<0.01$ & $<0.01$ & $<0.01$ \\
\hline $\begin{array}{l}\text { Serum K+ } \\
(\mathrm{mmol} / \mathrm{L})\end{array}$ & $5.00 \pm 0.79$ & $5.55 \pm 0.77$ & $6.17 \pm 0.89$ & $<0.05$ & $<0.01$ & $<0.01$ \\
\hline $\begin{array}{c}\text { Serum Ca2+ } \\
(\mathrm{mmol} / \mathrm{L})\end{array}$ & $1.05 \pm 0.16$ & $0.87 \pm 0.16$ & $0.83 \pm 0.08$ & $<0.01$ & $<0.01$ & $\begin{array}{c}>0.05 \\
\text { (NS) }\end{array}$ \\
\hline Serum Urea $(\mathrm{mg} / \mathrm{dL})$ & $26.86 \pm 8.7$ & $48.96 \pm 26.5$ & $88.82 \pm 34.5$ & $<0.01$ & $<0.01$ & $<0.01$ \\
\hline $\begin{array}{c}\text { Serum Creatinine } \\
(\mathrm{mg} / \mathrm{dL})\end{array}$ & $0.70 \pm 0.16$ & $0.94 \pm 0.54$ & $2.41 \pm 0.89$ & $\begin{array}{l}>0.05 \\
(\mathrm{NS})\end{array}$ & $<0.01$ & $<0.01$ \\
\hline Serum ALT (IU/L) & $39.82 \pm 10.3$ & $55.5 \pm 21.8$ & $73.5 \pm 33.2$ & 0.02 & $<0.01$ & $<0.01$ \\
\hline Serum AST (IU/L) & $73.6 \pm 20.45$ & $102.58 \pm 49$ & $156 \pm 26.7$ & $<0.01$ & $<0.01$ & $<0.01$ \\
\hline Serum ALP (IU/L) & $247 \pm 111$ & $330 \pm 124$ & $352 \pm 136$ & $<0.01$ & $<0.01$ & $\begin{array}{c}>0.05 \\
\text { (NS) }\end{array}$ \\
\hline Serum Albumin (g/dL) & $3 \pm 0.24$ & $2.63 \pm 0.5$ & $2.34 \pm 0.57$ & $<0.01$ & $<0.01$ & $<0.01$ \\
\hline $\begin{array}{l}\text { Prothrombin Time } \\
\text { (SEC) }\end{array}$ & $12.2 \pm 1.13$ & $18 \pm 4.8$ & $20.8 \pm 7.3$ & $<0.01$ & $<0.01$ & $<0.01$ \\
\hline
\end{tabular}

${ }^{*} p$ value: ANOVA and followed by post-hoc test applied.

This table depicts the statistically significance of all the biochemical parameter.

\begin{tabular}{|c|c|c|c|c|c|c|c|}
\hline Outcomes & \begin{tabular}{|c|} 
HIE-1 No. \\
$(\%)$ \\
\end{tabular} & $\begin{array}{c}\text { HIE-2 No. } \\
(\%)\end{array}$ & $\begin{array}{c}\text { HIE-3 No. } \\
(\%)\end{array}$ & $\begin{array}{c}\text { Total No. } \\
(\%)\end{array}$ & \begin{tabular}{|c|}
$\begin{array}{c}\text { P value* HIE-1 } \\
\text { vs HIE-2 }\end{array}$ \\
\end{tabular} & \begin{tabular}{|c|}
$\begin{array}{c}\text { P value* HIE-1 } \\
\text { vs HIE-3 }\end{array}$ \\
\end{tabular} & $\begin{array}{c}\text { P value* HIE-2 } \\
\text { vs HIE-3 } \\
\end{array}$ \\
\hline Mortality & 0 & $\begin{array}{c}2 \\
(2.3)\end{array}$ & $\begin{array}{c}27 \\
(65.9) \\
\end{array}$ & $\begin{array}{c}29 \\
(19.3)\end{array}$ & 0.4604 & $<0.0001$ & $<0.0001$ \\
\hline $\begin{array}{c}\text { Recovery without abnormal } \\
\text { movement/ FND and without } \\
\text { AED } \\
\end{array}$ & $\begin{array}{c}23 \\
(100)\end{array}$ & $\begin{array}{c}66 \\
(76.7)\end{array}$ & 0 & $\begin{array}{c}89 \\
(59.3)\end{array}$ & 0.0241 & $<0.0001$ & $<0.0001$ \\
\hline $\begin{array}{c}\text { Recovery with abnormal } \\
\text { movement/ FND and with } \\
\text { AED }\end{array}$ & 0 & $\begin{array}{c}18 \\
(21)\end{array}$ & $\begin{array}{c}14 \\
(34.1)\end{array}$ & $\begin{array}{c}32 \\
(21.4)\end{array}$ & 0.0371 & 0.0043 & 0.1087 \\
\hline Total & 23 & 86 & 41 & 150 & & & \\
\hline
\end{tabular}

*p value: Chi-square test applied.

Mortality was more in severe degree of asphyxia as compared to mild and moderate variety and it was statistically significant $(p<0.01)$. The chance of favourable outcome diminishes with severity of asphyxia $(p<0.05)$. Bad recovery was more in moderateto-severe degree as compared to the mild variety of asphyxia and they were statistically significant $(\mathrm{p}<0.01)$.

\begin{tabular}{|c|c|c|c|c|c|}
\hline Parameters & Level & Survival & Death & Total & P value ${ }^{* * *}$ \\
\hline \multirow{2}{*}{ Sodium } & Normal & $86(71 \%)$ & $2(7 \%)$ & $88(58.7 \%)$ & \\
\hline & Low & $35(29 \%)$ & $27(93 \%)$ & $62(41.3 \%)$ & 0.000 \\
\hline \multirow{2}{*}{ Potassium } & Normal & $41(34 \%)$ & $0(0 \%)$ & $41(27.33 \%)$ & \\
\hline & High & $80(66 \%)$ & $29(100 \%)$ & $109(72.67 \%)$ & 0.000 \\
\hline \multirow{2}{*}{ Calcium Ionised } & Normal & $32(26 \%)$ & $0(0 \%)$ & $32(21.3 \%)$ & \\
\hline & Low & $89(74 \%)$ & $29(100 \%)$ & $118(78.7 \%)$ & 0.000 \\
\hline \multirow{2}{*}{ Urea } & Normal & $60(49.6 \%)$ & $2(7 \%)$ & $62(41.3 \%)$ & \\
\hline & High & $61(50.4 \%)$ & $27(93 \%)$ & $88(58.7 \%)$ & 0.000 \\
\hline \multirow{2}{*}{ Creatinine } & Normal & $43(35.5 \%)$ & $1(3 \%)$ & $44(29.3 \%)$ & \\
\hline & High & $78(64.5 \%)$ & $28(97 \%)$ & $106(70.7 \%)$ & 0.000 \\
\hline \multirow{2}{*}{ ALT } & Normal & $70(58 \%)$ & $9(31 \%)$ & $79(53 \%)$ & \\
\hline & High & $51(42 \%)$ & $20(69 \%)$ & $71(47 \%)$ & .000 \\
\hline \multirow{2}{*}{ AST } & Normal & $68(56 \%)$ & $10(34 \%)$ & $79(53 \%)$ & \\
\hline & High & $53(44 \%)$ & $19(66 \%)$ & $71(47 \%)$ & 0.000 \\
\hline \multirow{2}{*}{ ALP } & Normal & $60(49.6 \%)$ & $13(45 \%)$ & $73(49 \%)$ & \\
\hline & High & $61(50.4 \%)$ & $16(55 \%)$ & $77(51 \%)$ & $>0.05$ \\
\hline \multirow{2}{*}{ Albumin } & Normal & $68(56 \%)$ & $9(31 \%)$ & $77(51 \%)$ & \\
\hline & Low & $53(44 \%)$ & $20(69 \%)$ & $73(49 \%)$ & .000 \\
\hline \multirow{3}{*}{$\begin{array}{l}\text { Prothrombin } \\
\text { Time }\end{array}$} & Normal & $\begin{array}{c}69 \\
(57 \%) \\
\end{array}$ & $\begin{array}{c}6 \\
(21 \%) \\
\end{array}$ & $\begin{array}{c}75 \\
(50 \%) \\
\end{array}$ & \\
\hline & High & $\begin{array}{c}52 \\
(43 \%)\end{array}$ & $\begin{array}{c}23 \\
(79 \%)\end{array}$ & $\begin{array}{c}75 \\
(50 \%)\end{array}$ & .000 \\
\hline & Total & 121 & 29 & 150 & \\
\hline \multicolumn{6}{|c|}{ Table 8. Different Biochemical Level with Outcomes } \\
\hline
\end{tabular}

*** p value: Chi-square test applied with the significance observed.

This table depicts the statistically significance of all the biochemical level at outcome. 


\begin{tabular}{|c|c|c|c|c|c|c|}
\hline Age at Death & HIE-2 No. (\%) & Mean X \pm SD day & HIE-3 No. (\%) & Mean X \pm SD day & Total No. (\%) & Mean X \pm SD day \\
\hline$<1$ day & 0 & \multirow{5}{*}{$3.5 \pm 0.5$} & $1(3.7)$ & \multirow{5}{*}{$3.8 \pm 1.2$} & $1(3.4)$ & \multirow{5}{*}{$3.8 \pm 1.19$} \\
\hline 1-3 day & $1(50)$ & & $10(37)$ & & $11(38)$ & \\
\hline 4-7 day & $1(50)$ & & $15(55.6)$ & & $16(55.2)$ & \\
\hline$>7$ day & 0 & & $1(3.7)$ & & $1(3.4)$ & \\
\hline Total & 2 & & 27 & & 29 & \\
\hline \multicolumn{7}{|c|}{ Table 9. Age at Death with Severity of Birth Asphyxia } \\
\hline
\end{tabular}

Most of the babies from HIE-3 group expired within 1 - 3 days (37\%) and 4 - 7 days (55.6\%). Mean age at death of babies with moderate asphyxia was $3.5 \pm 0.5$ day, severe asphyxia was $3.8 \pm 1.2$ day and as a whole was $3.8 \pm 1.19$ day.

\begin{tabular}{|c|c|c|c|c|c|c|c|c|}
\hline \multirow{2}{*}{$\begin{array}{c}\text { Severity of } \\
\text { Asphyxia }\end{array}$} & $\mathbf{1 - 3}$ & $\mathbf{4 - 7}$ & $\mathbf{8 - 1 4}$ & $\mathbf{> 1 4}$ & $\begin{array}{c}\text { Mean Age at } \\
\text { Discharge } \\
\text { X } \pm \text { SD day }\end{array}$ & $\begin{array}{c}\text { *P value } \\
\text { HIE-1 vs } \\
\text { HIE-2 }\end{array}$ & $\begin{array}{c}\text { *P value HIE-2 } \\
\text { vs HIE-3 }\end{array}$ & $\begin{array}{c}\text { *P value HIE- } \\
\mathbf{1} \text { vs HIE-3 }\end{array}$ \\
\hline HIE-1 (\%) & $11(47.8)$ & $12(52.2)$ & 0 & 0 & $3.8 \pm 0.8$ & $<0.05$ & $<0.05$ & $<0.05$ \\
\hline $\begin{array}{c}\text { HIE-2 } \\
(\%)\end{array}$ & 0 & $24(28.6)$ & $59(70.2)$ & $1(1.2)$ & $9.1 \pm 2.4$ & & & \\
\hline $\begin{array}{c}\text { HIE-3 } \\
(\%)\end{array}$ & 0 & 0 & $3(21.4)$ & $11(78.6)$ & $17.2 \pm 3.5$ & & \\
\hline \multicolumn{7}{|c|}{ Table 10. Age at Discharge with Severity of Birth Asphyxia } \\
\hline
\end{tabular}

*p value: ANOVA and followed by post-hoc test applied.

Mean age at discharge of HIE-1, HIE-2 and HIE-3 babies were $3.8 \pm 0.8$ day, $9.1 \pm 2.4$ day, $17.2 \pm 3.4$ day respectively. Duration of hospital stay increased with severity birth asphyxia as 'p' value $<0.05$.

\section{DISCUSSION}

The present study was undertaken to analyse the biochemical parameters of perinatal asphyxia and their relationship with the outcome.

In the present study mild, moderate and severely asphyxiated babies constituted $15.33 \%, 57.33 \%$ and $27.34 \%$ respectively (Table 1 ). Chiabi $A$ and Nguefack $S$ et al

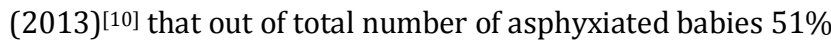
were HIE-1, 26\% were HIE-2 and 23\% were HIE-3. Mukesh Choudhary et al (2015)[7] in their study observed $14.28 \%$ were HIE-1; 25.73\% were HIE-2; 11.42\% were HIE-3. Hassan Boskabadi et al (2015)[11] in their study found HIE-1 were 11.86\%; HIE-2 were $45.76 \%$; HIE-3 were $42.37 \%$. Variation in incidence might be due to most of the cases admitted to our hospital as referred cases sent from other peripheral hospitals of Orissa, where most of the mild cases were managed and some of the mild cases stay with their mother at SCB Medical College and Hospital. Males outnumbered females $(77.3 \%$ vs $22.7 \%$ ) in the present study, even in three different degrees of asphyxia (mild- $56.5 \%$, moderate- $84.9 \%$, severe- $73.2 \%$ ). Male: Female ratio was 3.4: 1 . This study is well comparable with the results of Yvonne W. Wu et al (2004) ${ }^{[12]}$ who documented the association of ethnicity, male gender and low socio-economic status with increased incidence of birth asphyxia. Another study with similar outcome was found by Asad Nauman Kiyani et al (2014) ${ }^{[13]}$ with males (64\%) outnumbering females (36\%). Similar result was observed by Mahmoud H Ibrahim et al (2016)[14] with male sex accounting for $71.3 \%$. This difference may be due to more number of male asphyxiated babies who were brought to the hospital.

Incidence of severity of birth asphyxia increased with post maturity in HIE-2 and HIE-3 (HIE-1: 13\%, HIE-2: 45.3\%, HIE-3: $53.7 \%)$, which was statistically significant $(\mathrm{p}<0.01)$ (Table 2). A study by Sitthivuddhi Futrakul et al (2006) ${ }^{[15]}$ reported that inappropriate antenatal care, post-term gestation, vacuum extraction, male, prolapsed cord and low 1 and 5-minute Apgar scores were significant risk factors for HIE.

The present study showed that maximum number of birth asphyxia cases were seen in birth weight between 2500 $3000 \mathrm{gm}$ as evidenced by $87 \%, 61.6 \%, 58.5 \%$ in HIE- 1 , HIE- 2 and HIE-3 respectively (Table 4). Similar result was observed by Asad Nauman Kiyani (2014) ${ }^{[13]}$ with mean weight of the newborn was calculated as $2621.37( \pm 74.21)$ grams. Another study by Mahmoud H Ibrahim et al (2016)[14] found the mean weight to be $2.9 \pm 0.5 \mathrm{~kg}$.

In the present study, maximum number of birth asphyxia was more common in forceps/ ventouse delivery $(46.3 \%)$ which was statistically significant $(p<0.01)$. LSCS was mostly associated with mild degree of asphyxia and it was statistically significant $(p<0.01$ ) (Table 3 ). Itoo BA et al $(2003)^{[16]}$ study showed that incidence of birth asphyxia was more in normal vaginal delivery $(40 \%)$ and instrumental delivery (30\%) as compared to breech (9\%), emergency LSCS (21\%) and elective LSCS. Asad Nauman Kiyani et al (2014) [13] observed spontaneous vertex delivery in most commonly associated with birth asphyxia (44.39\%) followed by emergency caesarean section in $32.14 \%$ and $23.47 \%$ instrumental delivery. Also similar results were found in studies conducted by Gupta P et al (1997) ${ }^{[17]}$ and AS Daga et al (1990).[18]

The prolonged labour $(87.8 \%)$ and meconium stained liquor $(63.4 \%)$ were more commonly seen in severe degree of birth asphyxia and they were statistically significant $(\mathrm{p}<$ 0.01). NH and MRC (National Health and Medical Research Council) shows that the incidence of asphyxia to be higher in complicated pregnancies like PET, IUGR, APH, malpresentation and meconium stained liquor.[19] D Kaye et al (2003)[20] study showed that antepartum hospitalisation, antepartum/ intrapartum anaemia, APH, severe preeclampsia/ eclampsia, PROM, MSAF, vacuum extraction, LBW and malpresentation are significantly associated with birth asphyxia. 
Chiabi A et al (2013)[10] observed prolonged labour, arrest of labour, prolonged rupture of membrane, non-vertex presentation. Abnormal amniotic fluid (foul smell, meconium stained, yellowish) are strongly associated with higher incidence of birth asphyxia. Similar study result was found by Asad Nauman Kiyani in the year 2014.[13]

In the present study though birth asphyxia cases were more in primigravida mothers, but it was not significantly associated with the severity of birth asphyxia. Similarly, Sitthivuddhi Futrakul MD et al (2006)[15] and Tayyaba Khawar Butt et al (2008)[21] found no correlation between parity and HIE.

In the present study, incidence of severity of birth asphyxia increased with delivery outside the hospital (HIE-1: 8.7\% vs HIE-3: $48.8 \%$ ) as compared to the hospital delivery and it was statistically significant as ' $\mathrm{p}$ ' value was $<0.01$ (Table 5). Similar study were conducted by Rahana Majeed et al (2007)[22] and they have shown that incidence of birth asphyxia was more in home deliveries (56\%) as compared to hospital/ maternity home deliveries (40\%).

The mean values of different biochemical parameter with severity of asphyxia was statistically significant (Table 6). Basu et al (2010)[22] study showed that among the cases, hyponatraemia and hypocalcaemia developed early and simultaneously the decrease in their serum levels was directly proportional to each other and to the degree of asphyxia. Though, mean potassium level was within the normal limit, the value was higher among cases than controls and directly proportional to asphyxia. The outcome of present study was similar to Basu et al study, except the serum K+ level. Serum K+ was towards the higher side in this study, whereas it was within normal limit in the study conducted by Basu et al.

Jajoo et al (1995)[23] study showed that asphyxiated fullterm (AGA) as well as full-term (IUGR) infants had significantly lower serum calcium level than control infants. Similar result was found by BK Jain, Daljit Singh et al (2000) ${ }^{[24]}$ and Seema Rai et al (2015).[25] Najaf Masood et al (2016)[26] observed low sodium and low calcium level in asphyxiated group and concluded that hyponatraemia and hypocalcaemia showed linear co-relation with severity of birth asphyxia.

Similar result was observed by Rahman $\mathrm{F}$ and Siddique MAB et al[27] in the year 2017. Study by G Joag et al (2017)[28] showed similar result of decreased mean value of serum sodium, serum calcium and serum glucose in asphyxiated newborns, which had positive correlation with the severity of birth asphyxia.

Mishra et al (1991)[29] study has shown that decreased serum sodium and increased serum potassium, creatinine and blood urea nitrogen were consistently found in all cases of moderate-to-severe degree of birth asphyxia. The outcome of present study was similar to their study.

Prodhan MS, Moniruzzaman A, Majumder B, Rahman MJ, Suja-Ud-Doula A, Nabi SN and Mostakim MA (2017)[30] observed that babies with perinatal asphyxia developed hyponatraemia, hyperkalaemia, significant rise of serum creatinine and blood urea which was proportionate to the severity of asphyxia.

All the above biochemical parameters were affected in an increasing pattern from mild-to-severe degree of birth asphyxia, as their ' $p$ ' values were statistically significant. This is similar to the findings observed by Basu et al,[22] Gupta et al[31] and Mishra et al[29] study.

Our study for mean values of biochemical parameters with severity of birth asphyxia is similar to the findings observed by Mukesh Choudhry et al,[8] Karlsson M, WibergItzel E et al,[32] Tariqul I, Seikh AH et al in 2010[33] and Chaitali et al in 2016.[34]

Mortality was more in severe degree of asphyxia as compared to mild and moderate variety and it was statistically significant $(p<0.01)$. The chance of favourable outcome diminishes with severity of asphyxia $(p<0.05)$. Bad recovery was more in moderate-to-severe degree as compared to the mild variety of asphyxia and they were statistically significant ( $p<0.01$ ) (Table 9). Out of total 150 cases $19.3 \%$ cases expired, $59.3 \%$ cases discharged with no abnormal movement, FND or AED use and $21.4 \%$ cases developed abnormal movement, FND and discharged with AED use (Table 7).

C Robertson and N Finer et al (1985) ${ }^{[35]}$ studied outcome of 291 full-term infants with hypoxic-ischaemic encephalopathy as a function of severity of neonatal neurological syndrome and found that all cases of mild HIE had normal neurological outcome, whereas moderate and severe degree developed neurological sequelae in $24 \%$ and $20 \%$ of cases respectively. Mortality was $5 \%$ in moderate, but $80 \%$ in severe degree of birth asphyxia. Hassan Boskabadi et al (2006) ${ }^{[11]}$ found in their study that statistically significant association between HIE severity and long-term prognosis, i.e. with increase in severity of HIE incidence of developmental delay increases. The outcome of the present study was similar to their study.

The present study showed that hyponatraemia, hypocalcaemia, hyperkalaemia, high serum urea and creatinine levels were more in death group and were all statistically significant as ' $p$ ' value was $<0.05$ (Table 8). It was similar to the findings observed by Mishra et al,[29] Najaf Masood et al,[26] Rahman F et al[27] and Prodhan et al[30] in their studies.

Gupta et al (2005)[31] in their study has shown that severity of renal function abnormality correlates well with degree of asphyxia. Oliguria, hyponatraemia and abnormal sonographic scan are bad prognostic signs in renal failure secondary to birth asphyxia.

S Nouri et al (2008)[36] studied 87 cases of full-term neonates with perinatal asphyxia and found that neurologic examination was abnormal in 36 out of $72(50 \%)$ neonates without renal failure and in 9 of the $12(75 \%)$ survivors with renal failure. Among the 12 neonates with renal failure, 7 had abnormal neurologic features at discharge. Renal function assessment using plasma creatinine level seems to be correlated with neurologic outcome.

The present study showed that the increased level of serum ALT, AST, hypoalbuminaemia and prolonged prothrombin time were associated more with death groups $(69 \%, 66 \%, 55,69 \%, 79 \%)$ as compared to survival group (42\%, 44\%, 50.4\%, 44\%, 43\%) and they were statistically significant as ' $p$ ' value was $<0.001$ (Table No. 8). This study is similar to the findings observed by Mukesh Choudhary, ${ }^{[7]}$ Tariqul I et al[33] and Chaitali Patra et al..[34]

The Table 9 depicts that 2 babies from HIE- 2 group died, one within 1 - 3 days and the other one within $4-7$ days. 
Most of the babies from HIE-3 group expired within 1 - 3 days (37\%) and $4-7$ days (55.6\%). Mean age at death of babies with moderate asphyxia was $3.5 \pm 0.5$ days and severe asphyxia was $3.8 \pm 1.2$ days.

Table 10 shows that $11(47.8 \%)$ and $12(52.2 \%)$ cases of HIE-1 were discharged within 1 - 3 days and $4-7$ days respectively. Most of the cases of HIE-2 (70.2\%) were discharged within 8 - 14 days. 11 (78.6\%) cases of HIE-3 were discharged after day 14.

The mean age at discharge of HIE-1, HIE- 2 and HIE-3 babies were $3.8 \pm 0.8$ days, $9.1 \pm 2.4$ days, $17.2 \pm 3.4$ days respectively. The above findings can clearly conclude that duration of hospital stay increased with severity of birth asphyxia $(\mathrm{p}<0.05)$.

\section{Summary}

Out of 150 cases, moderate asphyxia constitutes majority 86 (57.33\%) of cases. Male babies outnumbered (77.3\%) female babies in all the three grades of birth asphyxia. The incidence of severity of birth asphyxia increases with post maturity $(\mathrm{p}<0.01)$. Maximum number of birth asphyxia cases [97(64.7\%)] were seen in the birth weight between 2500 $3000 \mathrm{gm}$. Severe degree of birth asphyxia was more common in forceps/ ventouse delivery (46.3\%) and it was statistically significant as ' $\mathrm{p}$ ' value was $<0.01$. Prolonged labour and meconium stained liquor were more commonly seen in severe degree of birth asphyxia and they were statistically significant ( $p$ value $<0.01$ ). Incidence of severity of birth asphyxia increased with delivery outside the hospital as compared to the hospital delivery and it was statistically significant ( $\mathrm{p}$ value $<0.01$ ). All the biochemical parameters like serum $\mathrm{Na}+\mathrm{K}+\mathrm{Ca}+2$, Urea, Creatinine, ALT, AST, ALP, Albumin and Prothrombin time were affected in an increasing pattern from mild-to-severe degree of birth asphyxia, as their ' $p$ ' values were statistically significant. Mortality was more in severe degree of asphyxia as compared to mild and moderate variety and it was statistically significant $(p<0.01)$. The chance of favourable outcome diminishes with severity of asphyxia $(p<0.05)$. Bad recovery was more in moderate-to-severe degree as compared to the mild variety of asphyxia and they were statistically significant ( $\mathrm{p}<0.01$ ). Cases of hyponatraemia, hypocalcaemia, hyperkalaemia, high serum urea and creatinine levels were more in death group (93\%, 100\%, 100\%, 93\%, 97\%) as compared to the group with survival group $(29 \%, 74 \%, 66 \%$, $50.4 \%, 64.5 \%)$ and they were all statistically significant ( $p$ value $<0.001$ )

The present study showed that the increased level of serum ALT, AST, hypoalbuminaemia and prolonged prothrombin time were associated more with death groups $(69 \%, 66 \%, 55,69 \%, 79 \%)$ as compared to survival group (42\%, 44\%, 50.4\%, 44\%, 43\%) and they were statistically significant as ' $p$ ' value was $<0.001$.

Mean age at death of babies with moderate asphyxia was $3.5 \pm 0.5$ days and severe asphyxia was $3.8 \pm 1.2$ days.

Mean age at discharge of HIE-1, HIE- 2 and HIE-3 babies were $3.8 \pm 0.8$ days, $9.1 \pm 2.4$ days, $17.2 \pm 3.4$ days respectively. Duration of hospital stay increased with severity of birth asphyxia $(\mathrm{p}<0.05)$.

\section{CONCLUSION}

It can be concluded that babies with perinatal asphyxia develop hyponatraemia, hypocalcaemia, hyperkalaemia, high serum urea and creatinine, high serum ALT, AST, ALP, decrease in serum albumin, increase in prothrombin time in proportion to the severity of asphyxia. Grossly asphyxiated babies may develop severe derangement of the above biochemical parameters, which may require immediate medical interventions. There is a definite correlation between the severity of birth asphyxia with dyselectrolytaemia, deranged renal function parameters, deranged hepatic enzymes, serum albumin and prothrombin time.

A significant number of babies with birth asphyxia and deranged biochemical parameters either died or discharged with severe neurological sequelae. It can be concluded that deranged biochemical parameters are early indicators of poor outcome.

Studies should be held on the effects of early correction of these metabolic derangements with their outcomes, so that it may invent a new horizon of treatment for birth asphyxia babies.

Timely and prompt resuscitation of newborn babies at birth, active and early management by therapeutic hypothermia in asphyxiated babies is highly essential to reduce the severity of birth asphyxia which can minimise the mortality and future neurological complications.

It is further recommended that the obstetricians, paediatricians as well as the paramedical workers need 'Neonatal Resuscitation Training,' which will definitely prevent birth asphyxia and indirectly help reducing IMR of the state.

\section{REFERENCES}

[1] NNPD Network. National Neonatal Perinatal Databasereport for the year 2002-2003. NNF NNPD network. New Delhi, 2005.

[2] Fisher DL, Fraser BJ. School climate: assessing and Improving School Environments. Set 1990: No. 2.

[3] McIntosh N. The newborn. In: McIntosh N, Helms PJ, Smyth LR, eds. Forfar \& Arneil's textbook of pediatrics. 7th edn. Newyork: Churchill Livingstone 2008:177392.

[4] The State of the World's Children, UNICEF, 2009.

[5] Basu P, Som S, Das H, et al. Electrolyte status in birth asphyxia. Indian J of Pediatrics 2010;77(3):259-62.

[6] Hansen AR, Soul JS. Perinatal asphyxia and hypoxicischemic encephalopathy. In: Cloherty JP, Eichenwald EC, Hansen AR, eds. Manual of neonatal care. $7^{\text {th }}$ edn. Philadelphia: Lippincott Williams \& Wilkins 2012;71128.

[7] Choudhary M, Sharma D, Dabi D, et al. Hepatic dysfunction in asphyxiated neonates: prospective case-controlled study. Clin Med Insights Pediatr 2015;9:1-6.

[8] Sarnat HB, Sarnat MS. Neonatal encephalopathy following fetal distress: a clinical and electroencephalographic study. Arch Neurol 1976;33(10):696-705.

[9] Fenichel GM. Hypoxic-ischemic encephalopathy in the newborn. Arch Neurol 1983;40(5):261-6. 
[10] Chiabi A, Nguefack S, Mah E, et al. Risk factors for birth asphyxia in an urban health facility in Cameroon: Iran. J Child Neurol 2013;7(3):46-54.

[11] Boskabadi H, Ashrafzadeh F, Doosti $H$, et al. Assessment of risk factors and prognosis in asphyxiated infants. Iran J Pediatr 2015;25(4):e2006.

[12] Wu YW, Backstrand KH, Zhao S, et al. Declining diagnosis of birth asphyxia in California: 1991-2000. Pediatrics 2004;114(6):1584-90.

[13] Kiyani AN, Khushdil A, Ehsan A. Perinatal factors leading to Birth Asphyxia among term newborns in a tertiary care hospital. Iran J Pediatr 2014;24(5):63742.

[14] Ibrahim MH, Asma MN. Perinatal factors preceding neonatall hypoxic-ischemic-encephalopathy in ElMinia locality. Gynecol Obstet (Sunnyvale) 2016;6(9):403.

[15] Futrakul S, Praisuwanna P, Thaitumyanon P. Risk factors for hypoxic-ischemic encephalopathy in asphyxiated newborn infants. J Med Assoc Thai 2006;89(3):322-8.

[16] Itoo BA, Al-Hawsawi ZM, Khan AH. Hypoxic ischemic encephalopathy incidence and risk factors in North Western Saudi Arabia. Saudi Med J 2003;24(2):147-53.

[17] Gupta P, Faridi MM, Behl D, et al. Clinical and biochemical asphyxia in meconium stained deliveries. Indian Pediatrics 1998;35(4):353-7.

[18] Daga AS, Daga SR, Patole SK. Risk assessment in birth asphyxia. Journal of Tropical Pediatrics 1990;36(1):34-9.

[19] National Health and Medical Research Council. Perinatal morbidity report of the health care committee expert panel on perinatal morbidity, Australian Government Publishing Service, 1995.

[20] Kaye D. Antenatal and intrapartum risk factors for birth asphyxia among emergency obstetric referrals in Mulago Hospital, Kampala, Uganda. East African Medical Journal 2003;80(3):140-3.

[21] Butt TK, Farooqui R, Khan MA. Risk factors for hypoxic ischemic encephalopathy in children. Journal of the College of Physicians and Surgeons Pakistan 2008;18(7):428-32.

[22] Majeed R, Memon Y, Majeed F, et al. Risk factors of birth asphyxia. J Ayub Med Coll Abbottabad 2007;19(3):67-71.

[23] Jajoo D, Kumar A, Shankar R, et al. Effect of birth asphyxia on serum calcium levels in neonates. Indian J Pediatr 1995;62(4):455-9.
[24] Jain BK, Singh D, Singh H, et al. Serum ionised calcium in birth asphyxia. Indian Journal of Clinical Biochemistry 2000;15(1):36-9.

[25] Rai S, Bhatiyani KK, Kaur S. Effect of birth asphyxia on serum calcium and glucose level: a prospective study. International Journal of Scientific Study 2015;3(7):3-6.

[26] Masood N, Munitha ST, Sharif M, et al. Correlation of serum electrolytes changes with severity of birth asphyxia in newborns. Journal of Rawalpindi Medical College 2016;20(1):27-9.

[27] Rahman F, Md Siddique AB, Md Hassan W, et al. A study on electrolyte imbalance in asphyxiated neonates. KYAMC Journal 2017;7(2):775-9.

[28] Joag G, Langade R, Aundhakar CD, et al. Study of serum sodium, serum calcium and blood glucose level in neonates with birth asphyxia. International Journal of Multidisciplinary Research and Development 2017;4(11):82-4.

[29] Mishra PK, Kumar A, Natu SM, et al. Renal failure in symptomatic perinatal asphyxia. Indian Pediatrics 1991;28(10):1147-51.

[30] Prodhan MS, Moniruzzaman A, Majumder B, et al. Serum electrolytes level and renal functional status in perinatal asphyxia. Dinajpur Med Col J 2017;10(1):127-32.

[31] Gupta BD, Sharma P, Bagla J, et al. Renal failure in asphyxiated neonates. Indian Pediatrics 2005;42(9):928-34.

[32] Karlsson M, Blennow M, Nemeth A, et al. Dynamics of hepatic enzyme activity following birth asphyxia. Acta Pediatr 2006;95(11):1405-11.

[33] Md Tariqul I, Seikh AH, Matin MA, et al. Alteration of hepatic function: helpful to diagnose and assess severity of perinatal asphyxia. Bangladesh J Child Health 2010;34(1):7-10.

[34] Patra C, Sarkar S, Dasgupta MK. Study of hepatic enzyme activity as a predictor of perinatal asphyxia and its severity and outcome. Indian Journal of Health Sciences Biomedical Research KLEU 2016;9(3):297302.

[35] Robertson C, Finer N. Term infants with hypoxicischemic encephalopathy: outcome at 3.5 years. Dev Med Child Neurol 1985;27(4):473-84.

[36] Nouri S, Mahdhaoui N, Beizig S, et al. Acute renal failure in full term neonates with perinatal asphyxia. Prospective study of 87 cases. Arch Pediatrics 2008;15(3):229-35. 